\title{
WYKONYWANIE ŚRODKÓW ODDZIAŁYWANIA PENITENCJARNEGO NA PRZESTRZENI LAT
}

\section{WSTĘP}

System penitencjarny jest tak efektywny, jak skuteczne są środki oddziaływania na więźniów. Umieszczenie osoby w instytucji totalnej, jaką jest zakład karny lub areszt śledczy, musi być podyktowane zarówno koniecznością wykonania orzeczonej kary, jak i zakładać, że skazaniec po zakończeniu okresu izolacji, wróci do społeczeństwa zmieniony, dostosowany do życia i panujących w nim norm oraz reguł. Do osiągnięcia wymienionych wyżej celów, niezbędne jest prawidłowe stosowanie, przewidzianych przepisami prawa, odpowiednich, zindywidualizowanych mechanizmów i procedur względem osadzonych.

Analogicznie do zmian zachodzących w społeczeństwie, powinny następować także $\mathrm{i}$ adekwatne zmiany w stosowaniu środków oddziaływania penitencjarnego. Inaczej wyglądał przekrój osadzonych w pierwszych latach obowiązywania Kodeksu karnego wykonawczego ${ }^{1}$, a inaczej wygląda on po ponad dwudziestu latach od dnia jego wejścia w życie. Ewolucja, która nastąpiła w polskim społeczeństwie na przestrzeni ostatnich kilkunastu lat, znalazła swoje odzwierciedlenie zarówno w sposobie oraz rodzaju popełnianych przestępstw, jak i w samych osobach dopuszczających się czynów zabronionych. Zmiany cywilizacyjne, w tym nieustanny rozwój technologiczny, objęły swoim zasięgiem także i „kryminały”.

W niniejszym opracowaniu zostaną przedstawione środki oddziaływania penitencjarnego stosowane na przestrzeni ostatnich czternastu lat, z punktowym

Dr Grzegorz Skrobotowicz - adiunkt w Katedrze Postępowania Karnego, Instytut Nauk Prawnych, Wydział Prawa, Prawa Kanonicznego i Administracji, Katolicki Uniwersytet Lubelski Jana Pawła II, Al. Racławickie 14, 20-950 Lublin; e-mail: grzegorz.skrobotowicz@kul.pl; https:// orcid.org/0000-0002-0882-0236

${ }^{1}$ Ustawa z dnia 6 czerwca 1997 r., Kodeks karny wykonawczy, Dz. U. z 2019 r., poz. 676 [dalej cyt.: k.k.w.]. 
wskazaniem danych statystycznych dla lat: 2005, 2012 oraz 2018. Wyróżnienie właśnie tych momentów czasowych podyktowane jest najwyższymi różnicami w ogólnej liczbie skazanych i ukaranych według grup i systemu odbywania kary pozbawienia wolności. Co istotne, w zakresie poszczególnych środków oddziaływania penitencjarnego wskazane lata, będą wykazywały różne tendencję, o czym szerzej w dalszej części tekstu.

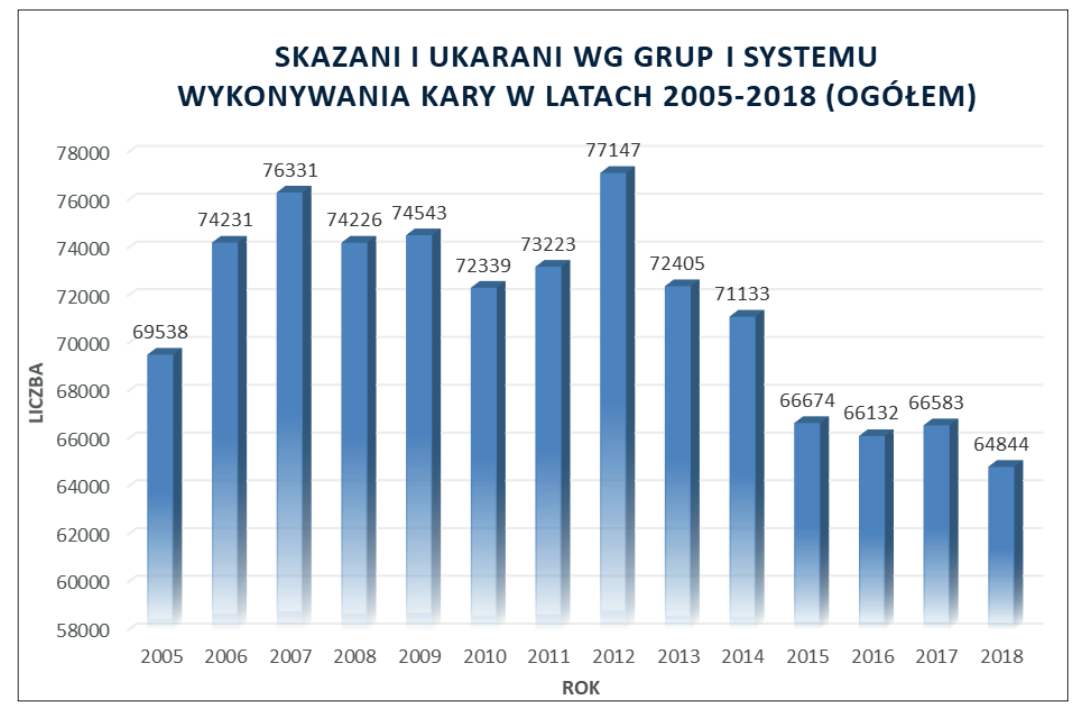

Wykres $\mathrm{nr}$ 1. Zestawienie danych statystycznych przedstawiających skazanych i ukaranych według grup i systemu wykonywania kary pozbawienia wolności w latach 2005-2018 (ogółem).

\section{I. ŚRODKI ODDZIAŁYWANIA PENITENCJARNEGO}

Reintegracja więźnia ze społeczeństwem prowadzona jest za pomocą oddziaływań korekcyjnych i pomocowych. Stanowią one realizację postulatu humanitarnego traktowania skazanych przy poszanowaniu ich godności ludzkiej².

Środki oddziaływania penitencjarnego stanowią narzędzie niezbędne do przygotowania skazanego do życia zgodnego z prawem i samodzielnego zarobkowania na własne utrzymanie ${ }^{3}$. Taki cel postępowania z więźniami został wyznaczony

\footnotetext{
2 N. PawŁowska, Prawo podmiotowe więźniów do powierzchni mieszkalnej, „Państwo i Prawo” 6 (2007), s. 84.

${ }^{3}$ Reguła 65 Wzorcowych reguł minimalnych postępowania z więźniami, przyjęte w Genewie w 1955 r. przez Pierwszy Kongres Narodów Zjednoczonych w Sprawie Zapobiegania Przestępczości i Postępowania ze Sprawcami Przestępstw i zaaprobowane przez Radę Gospodarczą i Społeczną
} 
w Regułach Minimalnych ONZ z 1955 r. Aby osiągnąć powyższe założenia, państwa zrzeszone w ramach ONZ, powinny stosować odpowiednie narzędzia i procedury w postaci zapewnienia m.in. opieki religijnej, edukacji, doradztwa oraz szkoleń zawodowych, wsparcia w zatrudnieniu, a w szczególności cechować się indywidualnym podejściem do każdego osadzonego ${ }^{4}$. Dnia 7 października 2015 r. Zgromadzenie Ogólne ONZ przyjęło rezolucję Standardy ONZ Minimum Traktowania Więźniów, tzw. Reguły Nelsona Mandeli ${ }^{5}$. Dokument ten stanowi zaktualizowaną wersją Reguł Minimalnych ONZ z 1955 r. i ma za zadanie ogólną poprawę sytuacji więźniów na świecie. Dla niniejszego opracowania znaczenie mają m.ni.: Reguła 87-88 odnoszące się do środków odziaływania penitencjarnego i mające na celu przygotowanie skazanego do powrotu do społeczeństwa po zakończeniu odbywania kary pozbawienia wolności. Dodatkowo, w Regułach 58-66, umieszczone zostały wymogi i standardy odnoszące się do skazanych w zakresie wspomagania ich $\mathrm{w}$ procesie reintegracji ze społeczeństwem oraz przygotowania do życia po opuszczeniu murów więzienia. Ma to zostać osiągnięte poprzez przyznanie prawa do utrzymywania kontaktów ze światem zewnętrznym, wykonywania praktyk religijnych oraz dostępu do biblioteki.

Z wytycznymi ONZ korespondują Europejskie Reguły Więzienne ${ }^{6}$. Zgodnie $\mathrm{z}$ treścią Reguły 6, w przypadku każdego pozbawienia wolności należy je wykonywać w taki sposób, aby ułatwić osadzonym reintegrację ze społeczeństwem. Tym samym, pozbawienie wolności jest formą odziaływania na skazanego nakierowaną na zmianę jego zachowania ${ }^{7}$.

Wskazane powyżej dokumenty prawa międzynarodowego stanowią tylko fragment dorobku wypracowanego na arenie międzypaństwowej wskazując podstawowe standardy i kierunki postępowania $\mathrm{z}$ więźniami ${ }^{8}$. Polskie ustawodawstwo karne jest zgodne z wypracowanymi normami. Artykuł $67 \S 3$ k.k.w. stanowi, że

w rezolucji 663C (XXIV) z dnia 31 lipca 1957 r. oraz rezolucji 2076 (LXII) z dnia 13 maja 1977 r. [dalej cyt.: Reguły Minimalne ONZ z 1955 r.].

${ }^{4}$ Reguła 66 (1) Reguł Minimalnych ONZ z 1955 r.

${ }^{5}$ Sesja siedemnasta, Trzeci Komitet - Wzorcowe reguły minimalne Organizacji Narodów Zjednoczonych dotyczące postępowania z więźniami (Reguły Mandeli), [w:] https://www.rpo.gov.pl/sites/ default/files/Reguly_Mandeli.pdf [dostęp:21.10.2019].

${ }^{6}$ Zalecenie Komitetu Ministrów Rady Europy dla państw członkowskich Rec (2006) 2 z dnia 11 stycznia 2006 r. w sprawie Europejskich reguł więziennych (przyjęte na 952 posiedzeniu wiceministrów), [w:] „Przegląd Więziennictwa Polskiego” 72-73 (2011), s. 33-69.

${ }^{7}$ J. Migdal, G. Sкroвотоwicz, Możliwość realizacji Europejskich Regut Więziennych z $2006 r$. w zakresie reintegracyjnego modelu wykonywania kary pozbawienia wolności a przeludnienie polskich jednostek penitencjarnych, „Rocznik Nauk Prawnych” 24 (2014), nr 1, s. 112.

${ }^{8}$ M.A. Nowicki, Wokót Konwencji Europejskiej. Komentarz do Europejskiej Konwencji Praw Człowieka, Warszawa: Wolters Kluwer 2013, s. 396. 
środkami oddziaływania penitencjarnego są, przede wszystkim: praca, nauczanie, zajęcia kulturalno-oświatowe i sportowe, podtrzymywania kontaktów z rodziną oraz światem zewnętrznym, a także środki terapeutyczne. Wszystkie one, mają za zadanie zachęcić skazanego do zmiany swojego dotychczasowego sposobu życia i wspomóc go w tym niełatwym procesie ${ }^{9}$.

Intensywność wykorzystania poszczególnych środków oddziaływania penitencjarnego, uzależniona jest w głównej mierze od systemu odbywania kary pozbawienia wolności oraz rodzaju zakładu karnego ${ }^{10}$. Największym impactem objęci są osadzeni zakwalifikowani z urzędu lub z własnego wyboru do systemu programowanego odziaływania. Jest on nakierowany na pracę ze skazanymi, którzy zasadniczo, z uwagi na młody wiek i brak wieloletniego skrzywienia kryminalną przeszłością, najbardziej są podatni na zmiany, a tym samym cel kary izolacyjnej winien być osiągnięty najefektywniej. W tym celu opracowywany zostaje, przy udziale skazanego, indywidualny program odziaływania, który stanowi swoistą mapę do osiągnięcia zakładanego rezultatu. Zaangażowanie więźnia, w proces opracowywania dedykowanego jemu indywidualnego programu odziaływania, jest przejawem programu naprawczego nakierowanego na zmianę dotychczasowego trybu życia przy użyciu adekwatnych środków oddziaływania penitencjarnego. Skazany, zarówno samodzielnie wskazując jak i godząc się na poszczególne etapy programu, zwiększa prawdopodobieństwo stosowania się do obopólnie zaakceptowanych oddziaływań.

\section{RODZAJE I TYPY ZAKŁADÓW KARNYCH}

W przypadku skazania na karę izolacyjną, sąd jest uprawniony do wskazania zarówno rodzaju, jak i typu zakładu karnego ${ }^{11}$. W przeciwnym wypadku decyzję w tym przedmiocie podejmie komisja penitencjarna (art. $76 \S 1$ pkt 1 k.k.w.). W poddanych analizie latach tj.: 2005, 2012 i 2018 rozłożenie więźniów w jednostkach penitencjarnych przedstawiało się w następująco:

\footnotetext{
${ }^{9}$ E. DAwIDZIUK, Traktowanie osób pozbawionych wolności we wspótczesnej Polsce na tle standardów międzynarodowych, Warszawa: Wolters Kluwer 2013, s. 139.

${ }^{10}$ Postepowanie z wybranymi grupami skazanych $w$ polskim systemie penitencjarnym. Aspekty prawne, red. A. Kwieciński, Warszawa: Wolters Kluwer Polska 2013, s. 310.

${ }^{11}$ Art. 62 ustawy z dnia 6 czerwca 1997 r. Kodeks karny, Dz. U. z 2019 r., poz. 1950 [dalej cyt.: k.k.].
} 
Tabela nr 1. Zestawienie danych statystycznych przedstawiających skazanych i ukaranych według grup i systemu wykonywania kary pozbawienia wolności w latach (stan na dzień 31 grudnia): 2005, 2012, $2018^{12}$.

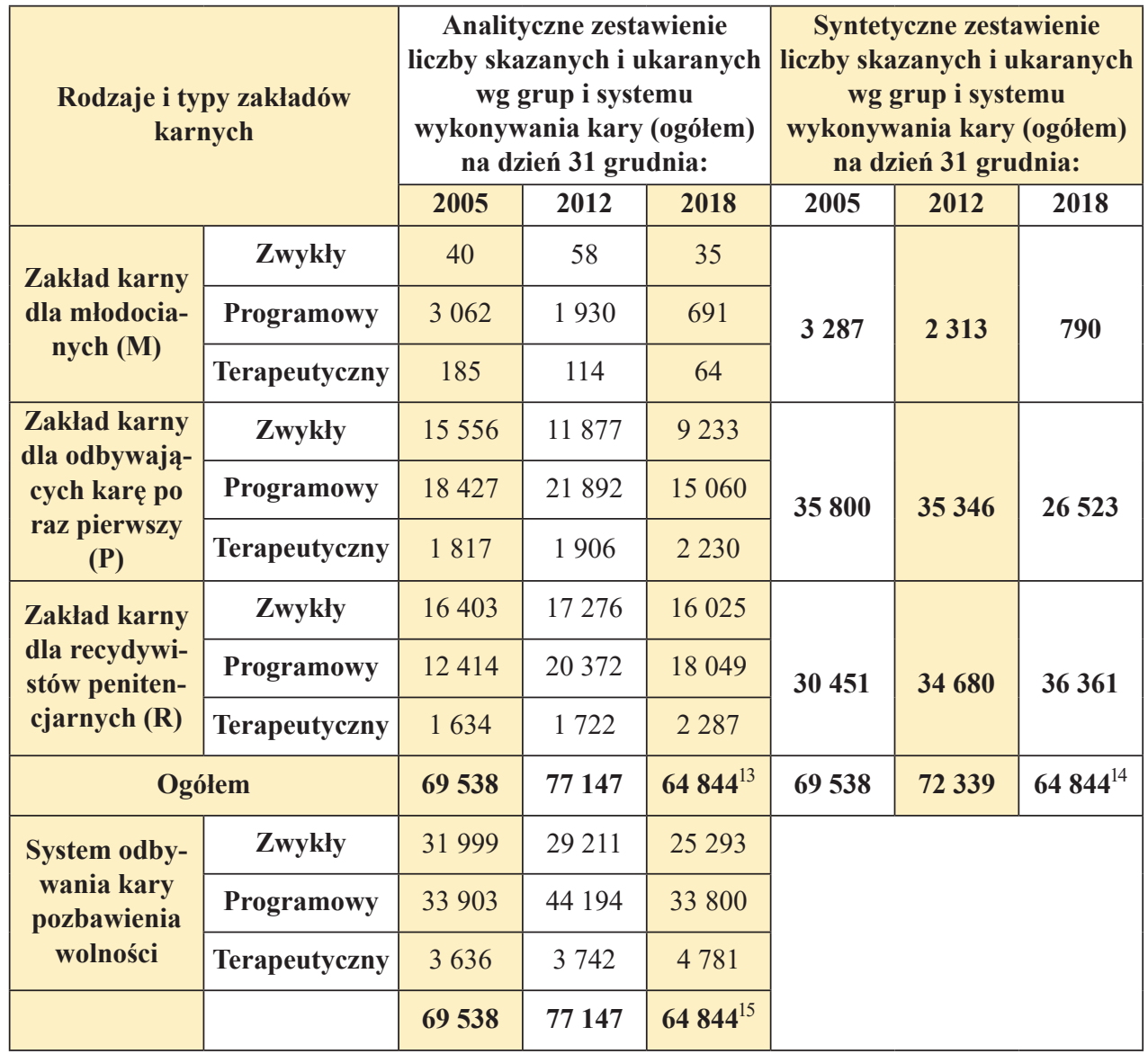

${ }^{12}$ Dane dostępne w statystykach corocznych Centralnego Zarządu Służby Więziennej, [w:] https:// www.sw.gov.pl/strona/statystyka-roczna [dostęp: 30.09.2019].

${ }^{13} \mathrm{~W}$ tym 970 osób nowoprzyjętych i oczekujących na I decyzję klasyfikacyjną.

${ }^{14} \mathrm{~W}$ tym 970 osób nowoprzyjętych i oczekujących na I decyzję klasyfikacyjną.

${ }^{15}$ W tym 970 osób nowoprzyjętych i oczekujących na I decyzję klasyfikacyjną. 


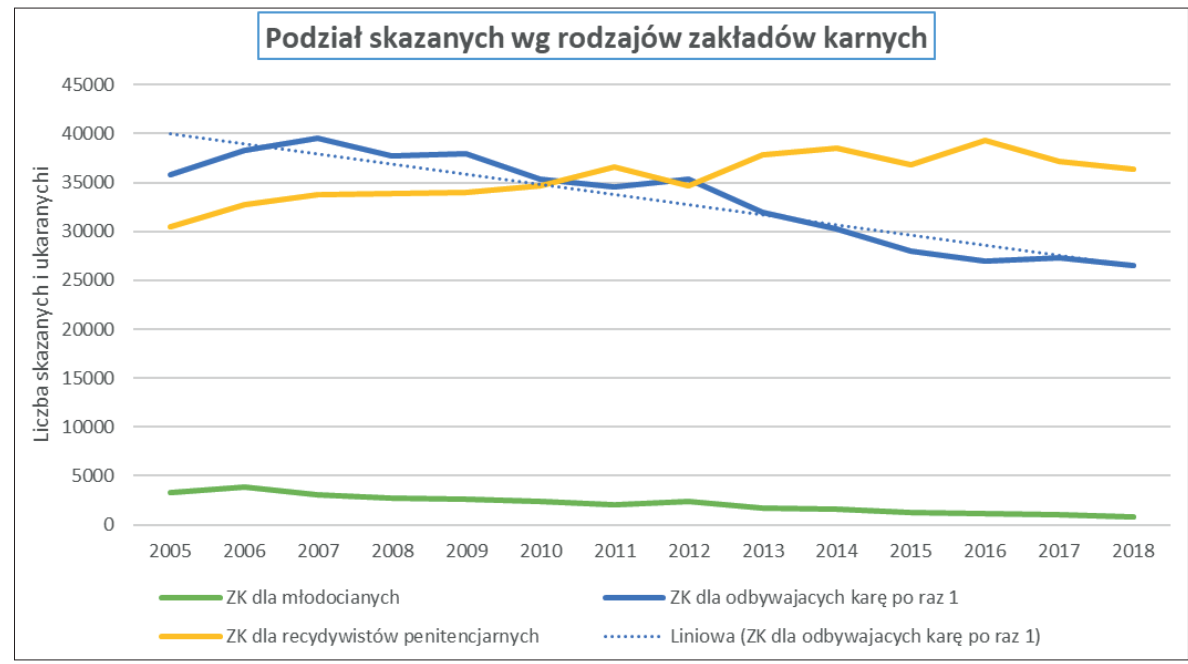

Wykres nr 2. Zestawienie liczby skazanych w poszczególnych rodzajach zakładów karnych w latach 2005-2018.

Dane, przedstawione w tabeli nr 1 oraz na wykresach nr 1 i 2, wskazują kilka istotnych tendencji dotyczących praktyki wykonywania kary pozbawienia wolności. Przede wszystkim, w 2018 r., w jednostkach penitencjarnych przebywała najmniejsza liczba skazanych i ukaranych według grup i systemów wykonywania kary, spośród wszystkich roczników, tj. 64.844 osoby. Najwięcej więźniów było w 2012 r. - 77.147 osób. Analizując dane statystyczne, publikowane przez Służbę Więzienną na stronach internetowych, widać wyraźny trend spadkowy poczynając od 2012 r. aż do 2018 r. ${ }^{16}$ Różnica pomiędzy tymi dwoma datami wynosi 12.303 osoby. Uzasadniony jest wniosek, że w kolejnych latach powinny być widoczne kolejne spadki, co należy ocenić jednoznacznie pozytywnie.

Po drugie, spośród wszystkich osób przebywających w zakładach karnych, w każdym z przedstawionych roczników, bezwzględnie najmniejsza liczba odbywała karę w zakładach karnych dla młodocianych, szczególnie liczba ta była niska w 2018 r. wynosząc ok. 1,2\% wszystkich osadzonych, jednocześnie w tym samym roku, największa liczba osób przebywała w zakładach karnych dla recydywistów penitencjarnych ok. $56,1 \%$ populacji.

Wzrost liczby recydywistów penitencjarnych w $2018 \mathrm{r}$. jest wynikiem niepokojącym. Koresponduje z danymi z 2005 r. i 2012 r. We wskazanych dwóch latach, największa liczba skazanych osadzona była w zakładach karnych dla odbywających karę po raz pierwszy, odpowiednio 35.800 osób w 2005 r. i 35.346 osób

${ }^{16}$ Zob. wykres nr 1. 
w 2012 r. Więźniowie, z tych jednostek penitencjarnych, dopuścili się popełnienia takich kolejnych przestępstw, które spowodowały zaklasyfikowanie ich do grupy recydywistów penitencjarnych (art. $86 \S 1$ i 2 k.k.w.).

Zwiększająca się populacja recydywistów penitencjarnych wskazuje na rosnący w Polsce wskaźnik recydywy, co prowokuje pytanie o skuteczność działań resocjalizacyjnych podejmowanych względem więźniów. Pozytywnym zjawiskiem jest zmniejszająca się liczba młodocianych skazańców. Porównując lata 2005 z 2018 widać ponad czterokrotny spadek liczebny z tej grupy więźniów. Linia trendu pokazuje, co do zasady, malejącą liczbę tych osadzonych przez cały analizowany okres.

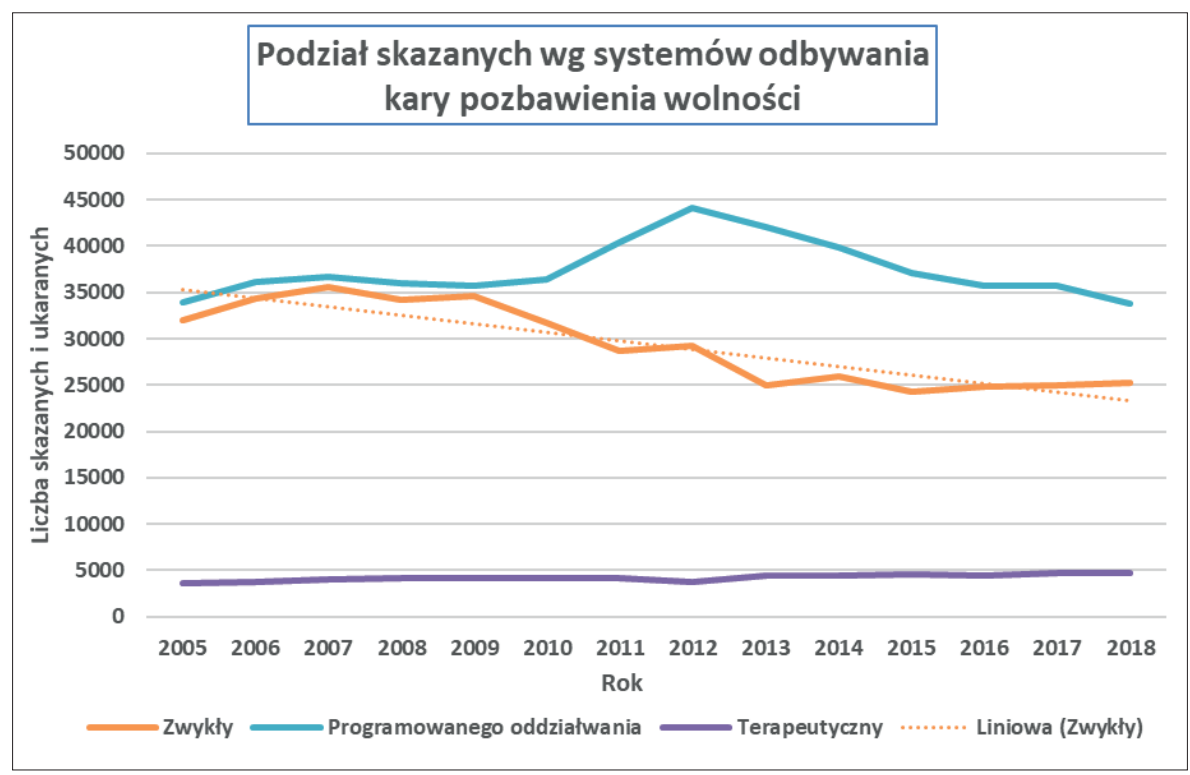

Wykres nr 3. Zestawienie liczby skazanych odbywających karę pozbawiania wolności w poszczególnych systemach w latach 2005-2018.

W ramach systemów odbywania kary pozbawienia wolności również widoczne są prawidłowości. Dane statystyczne potwierdzają realizację wymogu z art. $95 \S$ 1 k.k.w., zgodnie z którym młodociani przestępcy skazani na karę pozbawienia wolności odbywali ją, w większości przypadków, w systemie programowanego oddziaływania. System ten, najbardziej nakierowany na odziaływanie w ramach przyjętych programów na więźnia, we wszystkich latach ogólnie stosowany był najczęściej ${ }^{17}$.

${ }^{17}$ Należy poczynić uwagę, że co prawda w 2005 r. najczęściej stosowany był system programowanego oddziaływania, to jednak w przypadku zakładu karnego dla recydywistów penitencjar- 
Szczególnie zmianę i wzrost zainteresowania systemem programowanego oddziaływania widać w zakładach karnych dla recydywistów penitencjarnych. W 2005 r. przeważał tam system zwykły, natomiast zarówno w 2012 r., jak i kolejnych latach włącznie z 2018 r., ustąpił on miejsca systemowi programowanego oddziaływania. Odbywanie kary w tym systemie, co prawda niesie ze sobą określone przepisami przywileje, co może uzasadniać jego wybór także przez osoby zakwalifikowane, jako recydywiści penitencjarni, ale jednocześnie wymaga realizacji wyznaczonych programów i przyjętych w nich efektów. W przypadku braku postępów w realizacji zakładanych celów, nastąpi zmiana systemu odbywania kary pozbawienia wolności.

Rosnąca liczba recydywistów penitencjarnych, która jest niepokojącą, w zestawieniu z rosnącą liczbą osadzonych odbywających karę w systemie programowanego oddziaływania może prowadzić do wniosku, że skazani, którzy uprzednio przebywali w izolacji i objęci byli systemem zwykłym, nie dostrzegli dla siebie na tyle pozytywnych bodźców, aby zachęcić ich do przemiany. W rezultacie, po zakończeniu odbywania kary pozbawienia wolności powrócili do przestępczości. Tym samym, poddanie się obecnie przez tę grupę więźniów systemowi programowanego oddziaływania, jako tego najbardziej ,inwazyjnego” i wymagającego od skazańca, ocenić należy pozytywnie. Czy jednak ta zmiana spowoduje zmniejszenie się w kolejnych latach populacji recydywistów penitencjarnych? Na to pytanie udzielenie odpowiedzi będzie możliwe za kilka lat.

Niezależnie od systemu, w którym odbywa się karę izolacyjną, oraz rodzaju zakładu karnego, najistotniejsze znaczenie odgrywa postawa samego więźnia, jego chęć do dokonania jakiejś zmiany w swoim dotychczasowym życiu. Środki oddziaływania penitencjarnego mogą jedynie wspierać, stymulować i inicjować pożądane przez prawo i społeczeństwo zachowania.

\section{ODPŁATNE I NIEODPŁATNE ZATRUDNIANIE WIĘŹNIÓW}

Pierwszym ze środków oddziaływania penitencjarnego, wymienionym w art. 67 $\S 3$ k.k.w., jest zatrudnienie skazanego. Stanowi ono podstawowy instrument w procesie reintegracji więźnia ze społeczeństwem. To jak istotną rolę odgrywa praca dla więźnia, podkreślają dokumenty międzynarodowe, traktujące o problematyce praw i obowiązków osób pozbawionych wolności. Na arenie międzynarodowej, trzy podstawowe standardy, którymi należy się kierować przy wykonywaniu oddziaływań penitencjarnych to: po pierwsze, umożliwienie podjęcia zatrudnienia jak największej

nych system zwykły, nieznacznie, ale jednak był stosowany częściej niż system programowanego oddziaływania - zob. Tabela $\mathrm{nr} 1$. 
liczbie skazańców, z uwzględnieniem posiadanego doświadczenia lub wykształcenia albo zmierzającego do nabycia nowych umiejętności i kompetencji. Po drugie, jeżeli praca jest wykonywana odpłatnie to zapewnienie godziwego wynagrodzenia, oraz po trzecie poszukiwanie miejsc pracy i zatrudnianie więźniów poza obrębem jednostki penitencjarnej, co w przyszłości może umożliwić kontynuowanie zatrudnienia u danego pracodawcy po zakończeniu wykonywania kary izolacyjnej.

Europejski Komitet do spraw Zapobiegania Torturom oraz Nieludzkiemu lub Poniżającemu Traktowaniu albo Karaniu ${ }^{18}$ w raportach podkreśla znaczenie tego środka oddziaływania penitencjarnego, wskazując jednocześnie, że sama praca i jej rodzaj nie może stanowić dodatkowej dolegliwości wynikającej z wykonywania kary wolnościowej ${ }^{19}$.

Instytucje międzynarodowe podkreślają, że zatrudnienie jest prawem, a nie obowiązkiem skazanego. Jednocześnie art. 4 ust. 3 lit. a Konwencji o Ochronie Praw Człowieka i Podstawowych Wolności ${ }^{20}$, stanowi, że ,[...] pojęcie «praca przymusowa lub obowiązkowa nie obejmuje»: żadnej pracy, jakiej wymaga się zwykle w ramach wykonywania kary pozbawienia wolności [...]”. Tym samym, polskie ujęcie pracy, głównie jako obowiązku, a nie prawa podmiotowego więźnia, nie stoi w sprzeczności z prawem międzynarodowym.

Procent zatrudnienia osób pozbawionych wolności w polskich zakładach karnych stanowi przedmiot każdorazowej analizy $\mathrm{w}$ trakcie przeprowadzania prewencyjnych wizytacji przez Krajowy Mechanizm Prewencji Tortur [dalej cyt.: KMPT]. W raportach za 2010 oraz 2012 r. KMPT wskazał, że skazani zatrudniani byli głównie na terenie miejsc detencji, w których się znajdują, m.in. pracując na kuchni czy w pralni, w tym także nieodpłatnie. Podjęcie pracy u zewnętrznych pracodawców stanowiło mniejszościowe przypadki ${ }^{21}$. W raporcie za 2018 r. $^{22}$, pozytywnie oceniono „reformę Ministerstwa Sprawiedliwości w zakresie upowszechniania zatrudnienia osadzonych $\mathrm{w}$ jednostkach penitencjarnych zawartą $\mathrm{w}$ programie Praca dla więźniów"23. Potwierdzenie słuszności tej oceny widoczne jest w danych statystycznych prezentowanych przez Służbę Więzienną.

\footnotetext{
${ }^{18}$ The European Committee for the Prevention of Torture and Inhuman or Degrading Treatment or Punishment [dalej cyt.: CPT].

${ }^{19}$ DawidZIUK, Traktowanie osób pozbawionych wolności, s. 182.

${ }^{20}$ Konwencja o Ochronie Praw Człowieka i Podstawowych Wolności sporządzona w Rzymie dnia 4 listopada 1950 r., zmieniona następnie Protokołami nr 3, 5 i 8 oraz uzupełniona Protokołem nr 2, Dz. U. z 1993 r. Nr 61, poz. 284 [dalej cyt.: EKPCz].

${ }^{21}$ Raport Rzecznika Praw Obywatelskich z działalności w Polsce Krajowego Mechanizmu Prewencji w roku 2010 i 2012, s. 74.

${ }^{22}$ Raport Rzecznika Praw Obywatelskich z działalności w Polsce Krajowego Mechanizmu Prewencji w roku 2018, s. 132.

${ }^{23}$ Zob. https://www.sw.gov.pl/strona/ministerialny-program-pracy-wiezniow [dostęp: 2.11.2019].
} 
Tabela nr 2. Skala zatrudnienia i płacy skazanych w latach 2005, 2012 i $2018^{24}$.

\begin{tabular}{|c|c|c|c|}
\hline Wyszczególnienie & $\mathbf{2 0 0 5}$ & $\mathbf{2 0 1 2}$ & $\mathbf{2 0 1 8}$ \\
\hline $\begin{array}{c}\text { Średnia powszechność zatrudnienia } \\
\text { skazanych i ukaranych w \% }\end{array}$ & 28,2 & 30,4 & 54,3 \\
\hline $\begin{array}{c}\text { Średnia liczba zatrudnionych odplatnie } \\
\text { skazanych i ukaranych }\end{array}$ & 12207 & 9426 & 16969 \\
\hline $\begin{array}{c}\text { Średnia liczba zatrudnionych nieodplatnie } \\
\text { skazanych i ukaranych }\end{array}$ & 7089 & 13958 & 19232 \\
\hline $\begin{array}{c}\text { Średnia placa w zlotych polskich } \\
\text { Średnia stawka za roboczą godzinę } \\
\text { w zlotych polskich }\end{array}$ & 347,06 & 1036,91 & 1457,73 \\
\hline
\end{tabular}

\section{PROCENT ZATRUDNIENIA SKAZANYCH}

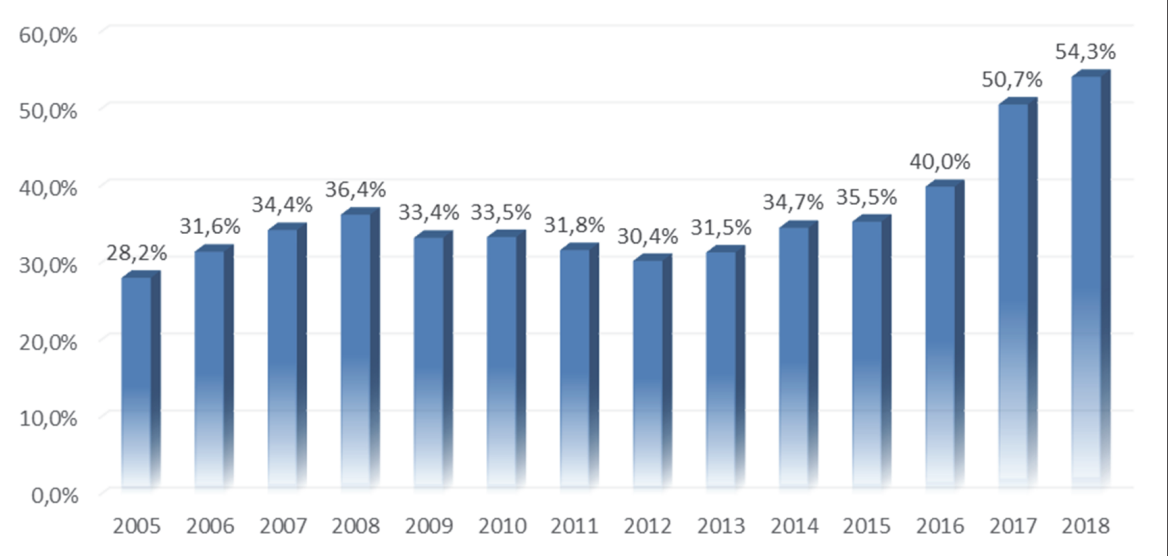

Wykres nr 4. Zestawienie procentowe zatrudnienia skazanych w latach 2005-2018.

Analizując przyjęte trzy punkty czasowe widać znaczące zmiany we wszystkich badanych obszarach. Po pierwsze średnia powszechność zatrudnienia skazanych i ukaranych liczona w procentach wzrosła prawie dwukrotnie - w 2005 r. wynosiła 28,2\%, natomiast w 2018 r. już 54,3\%. Jednocześnie rok 2005, obok roku 2012 charakteryzował się najniższym procentem zatrudnionych skazanych. A contrario

${ }^{24}$ Opracowane na podstawie corocznych informacji statystycznych Centralnego Zarządu Służby Więziennej, www.sw.gov.pl [dostęp: 30.09.2019]. 
od 2012 r. widoczna jest tendencja wzrostowa, szczególnie dynamiczna w latach 2015-2018 r. (wzrost o prawie $20 \%$, z poziomu $35,5 \%$ do poziomu $54,3 \%$ ).

Po drugie, o ponad cztery i pół tysiąca osób, zwiększyła się liczba więźniów zatrudnionych odpłatnie. Jeszcze bardziej wzrosła liczba skazanych i ukaranych pracujących nieodpłatnie, bowiem ten wzrost jest prawie trzykrotny.

Po trzecie, zarówno średnia stawka za roboczogodzinę, jak i powiązana z nią średnia płaca, zwiększyły się diametralnie. W 2005 r. średnia płaca wynosząca 347,06 zł zwiększyła się w 2012 r. do 1.036,91 zł ${ }^{25}$ i następnie wzrosła aż do kwoty 1.457,763 zł w 2018 r. Zwiększenie średniej płacy korespondowało ze zwiększaniem się płacy minimalnej, która szczególnie w latach 2015-2018 istotnie rosła ${ }^{26}$. Jeżeli w kolejnych latach zostanie wdrożona w życie deklaracja partii rządzącej dotycząca wzrostu wynagrodzenia minimalnego to znajdzie to przełożenie na średnią płacę więźniów ${ }^{27}$.

Uzasadniony jest wniosek, że środek oddziaływania penitencjarnego, jakim jest zatrudnienie skazanych, uległ znacznemu polepszeniu we wszystkich badanych płaszczyznach. Polski system penitencjarny, wsparty zmianami gospodarczymi, stara się zatem realizować międzynarodowe standardy i zalecenia wskazywane w raportach pokontrolnych tworzonych w poprzednich latach.

\section{KSZTAŁCENIE SKAZANYCH W TRAKCIE IZOLACJI PENITENCJARNEJ}

Edukacja skazanych, obok zatrudniania, stanowi główny środek oddziaływania penitencjarnego przewidzianego przez przepisy k.k.w. Podstawowym celem stosowania tego narzędzia jest umożliwienie więźniom nabycia nowych kompetencji oraz wiedzy. Ukończenie przerwanego etapu edukacji lub kontunuowania nauki, po opuszczeniu miejsca detencji wpłynie na zwiększenie wartości i znaczenia byłego więźnia na rynku pracy ${ }^{28}$.

Zarówno KMPT jak i $\mathrm{CPT}^{29}$ w raportach podkreślają konieczność stosowania szerokiego wachlarza oddziaływań penitencjarnych na osadzonych w celu pobudze-

\footnotetext{
${ }^{25} \mathrm{Na}$ ten wzrost bezpośredni wpływ miał wyrok Trybunału Konstytucyjnego z dnia 23 lutego 2010 r., sygn. akt P 20/09.

${ }^{26}$ Płaca minimalna (brutto) w Polsce w latach: 2005 - 849, 2006 - 899, 2007 - 936, $2008-$ 1.126, $2009-1.276,2010-1.317,2011-1.386,2012-1.500,2013-1.600$ zł, $2014-1.680$. zł, 2015 $-1.750 \mathrm{zl}, 2016-1.850 \mathrm{zl}, 2017-2.000 \mathrm{zl}, 2018-2.100 \mathrm{zl}, 2019-2.250$.

${ }^{27} \mathrm{https}$ ://www.gazetaprawna.pl/artykuly/1429363,pensja-minimalna-skutki-pis-program-wyborczy-ceny-firmy.html [dostęp 17.10.2019].

${ }^{28}$ M. Kuć, Indywidualizacja wykonywania kary pozbawienia wolności, Lublin: Towarzystwo Naukowe KUL 2007, s. 125.

${ }^{29}$ DAwidziUK, Traktowanie osób pozbawionych wolności, s. 193.
} 
nia ich do pożądanej aktywności, w tym edukacyjnej, oraz wskazania możliwości zdobycia wykształcenia tożsamego z tym, które posiadają osoby przebywające na wolności. Szczególnie istotne jest objęcie szerokim oddziaływaniem młodocianych skazanych, bowiem fakt popełnienia przestępstwa niejednokrotnie przerywał dotychczasową edukację i uniemożliwiał podjęcie kolejnego etapu zdobywania wiedzy. Ta grupa osadzonych, odbywając karę pozbawienia wolności w systemie programowanego odziaływania, obowiązana jest do udziału w wyznaczonych programach, co w praktyce oznacza ich dalsze kształcenie. Szczególne znaczenie ma pozyskanie przez młodych ludzi konkretnego zawodu, na wykonywanie którego, występuje zapotrzebowanie na rynku pracy. Niejednokrotnie młodociani sprawcy przestępstw, wywodzą się ze środowisk patologicznych, a dla członków ich rodzin gruntowne wykształcenie nie odgrywało istotnej roli. Powrót do takiego otoczenia, bez osiągnięcia określonego poziomu edukacji, w znacznym stopniu utrudni dalsze, normalne życie, w którym wykonuje się legalną pracę i nie popada w konflikt z prawem. Stąd, zarówno w ocenie organizacji międzynarodowych, jak i rodzimego ustawodawstwa, edukacja i proces dalszego kształcenia odgrywa znaczącą rolę.

Liczba skazanych i ukaranych objętych nauczaniem w analizowanych latach wykazuje stabilizację w poszczególnych palcówkach edukacyjnych.

Tabela nr 3 Osadzeni objęci nauczaniem w szkołach przywięziennych

i pozawięziennych w latach szkolnych 2004/2005, 2011/2012 oraz 2017/2018 ${ }^{30}$.

\begin{tabular}{|c|c|c|c|}
\hline Wyszczególnienie & $\begin{array}{c}\text { Rok szkolny } \\
\mathbf{2 0 0 4 / 2 0 0 5}\end{array}$ & $\begin{array}{c}\text { Rok szkolny } \\
\mathbf{2 0 1 1 / 2 0 1 2}\end{array}$ & $\begin{array}{c}\text { Rok szkolny } \\
\mathbf{2 0 1 7 / 2 0 1 8}\end{array}$ \\
\hline Szkoły podstawowe & 35 & 24 & 39 \\
\hline Gimnazja & 391 & 360 & 78 \\
\hline Zasadnicze szkoły zawodowe & 2161 & 1915 & $2893^{31}$ \\
\hline Technika Zawodowe & 504 & 354 & - \\
\hline Licea Zawodowe/szkoły policealne & 18 & 125 & 83 \\
\hline Licea ogólnokształcące & 553 & 368 & 1000 \\
\hline Szkoły Wyższe & 28 & 55 & 10 \\
\hline Ogółem & $\mathbf{3 ~ 8 8 0}$ & $\mathbf{3 2 0 1}$ & $\mathbf{4 1 0 3}$ \\
\hline
\end{tabular}

${ }^{30}$ Opracowane na podstawie corocznych informacji statystycznych Centralnego Zarządu Służby Więziennej, https://www.sw.gov.pl [dostęp: 30.09.2019].

${ }^{31}$ Kwalifikacyjne kursy zawodowe. 


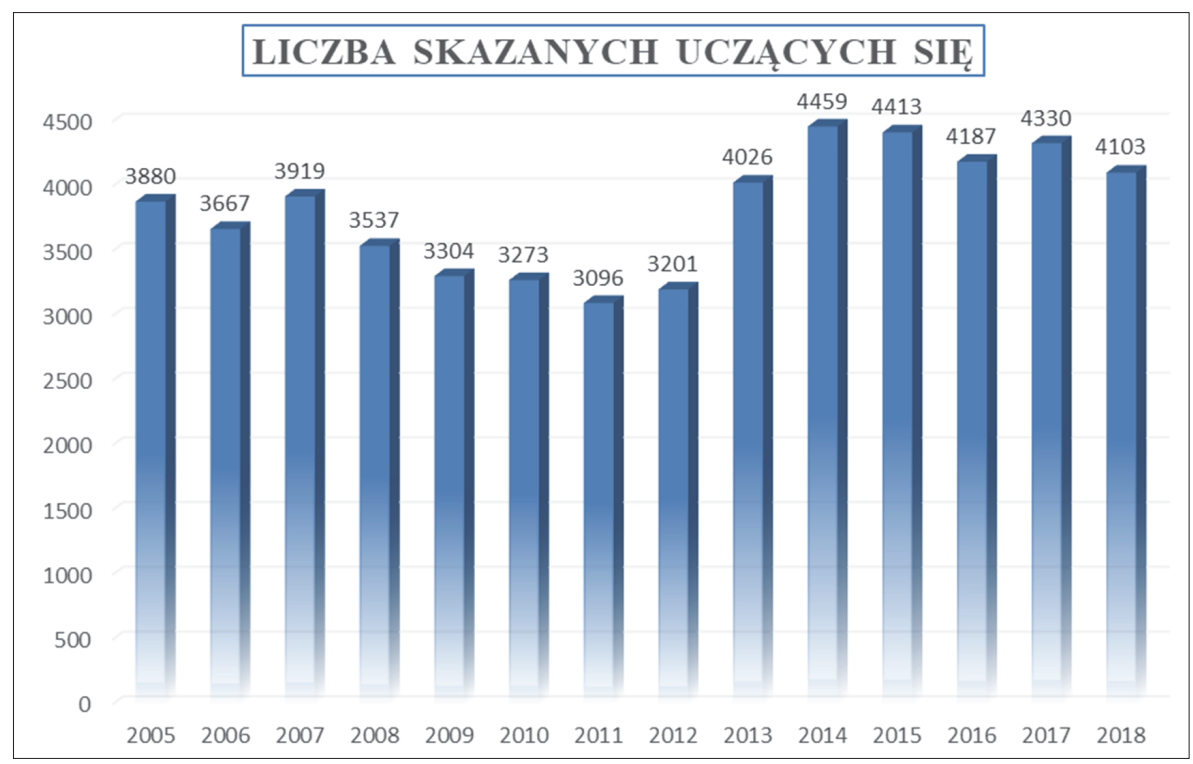

Wykres nr 5. Zestawienie liczby skazanych uczących się w różnych placówkach oświatowych w latach 2005-2018.

Dane z wykresu nr 5 wskazują, że tylko niewielki procent, tj. między 5\%-8\%, więźniów, podnosi swoje wykształcenie w trakcie odbywania kary pozbawienia wolności. Największa grupa ${ }^{32}$, ponad $70 \%$ z tej populacji, uczęszcza do zasadniczych szkół zawodowych. Drugim najczęściej wybieranym szczeblem edukacji, niespełna 25\%, jest liceum ogólnokształcące. Pozostałe formy edukacji stanowią śladową liczbę, szczególnie liczba abiturientów szkoły wyższej jest znikoma.

Przedstawiona niska frekwencja osób uczestniczących w procesie edukacji związana jest również o ograniczeniami wynikającymi z przepisów ustawy. Kodeks karny wykonawczy przewiduje pewne restrykcje, co do kierowania skazanych do nauczania. Dotyczy to przede wszystkim wprowadzenia ograniczenia czasowego związanego z okresem pozostałym do zakończenia wykonywania kary. Paragraf 14 rozporządzenia Ministra Sprawiedliwości w sprawie szczegółowych zasad $\mathrm{i}$ trybu prowadzenia nauczania $\mathrm{w}$ zakładach karnych ${ }^{33}$, wydany na podstawie art. 134 k.k.w., stanowi, że do nauczania w szkole kwalifikuje się skazanych, jeżeli czas pozostały do zakończenia odbywania kary nie jest krótszy niż okres trwania nauki w szkole. Również przyznanie prymatu nauczania osobom odbywającym

\footnotetext{
32 Zob. tabela nr 3.

${ }^{33}$ Rozporządzenie Ministra Sprawiedliwości z dnia 12 grudnia 2016 r. w sprawie sposobu i trybu prowadzenia nauczania w zakładach karnych i aresztach śledczych, Dz. U. poz. 2004 z późn. zm.
} 
karę w systemie programowego oddziaływania istotnie zawęża krąg osób, którzy zostaną nim objęci, co nie koresponduje z postulatem dostępności nauczania dla wszystkich skazanych. Przepisy prawa polskiego realizują międzynarodowy standard dotyczący szczególnej troski o wykształcenie młodocianych, wprowadzając obowiązek objęcia nauczaniem osadzonych, którzy nie ukończyli 18 roku życia, zobowiązanych do realizacji obowiązku szkolnego.

Przesłanką zachęcającą do podjęcia się nauki i ukończeniem kolejnego stopnia edukacji jest wygląd i treść świadectwa ukończenia placówki oświatowej. Paragraf § 21 ust. 1 wyżej wymienionego rozporządzenia stanowi, że osadzony, który w trakcie odbywania kary pozbawienia wolności ukończył szkołę, otrzymuje świadectwo, które nie może zawierać informacji o uzyskaniu go w czasie wykonywania kary pozbawienia wolności. Tym samym więzień nie jest objęty stygmatyzacją wynikającą z ukończenia szkoły w warunkach izolacji penitencjarnej. Regulacja ta wpisuje się w międzynarodowe standardy i uwagi zgłaszane przez CPT.

\section{ZAJĘCIA KULTURALNO-OŚWIATOWE ORAZ SPORTOWE}

W celu zachowania prawidłowego balansu pomiędzy pracą, edukacją oraz odpoczynkiem skazanego, przewidziane zostały w k.k.w. odpowiednie środki oddziaływania penitencjarnego służące temu zadaniu. Umożliwienie więźniom korzystania z różnych form aktywności wskazywane jest również przez regulacje międzynarodowe. Fakt umieszczenia osoby w jednostce detencyjnej, nie może wykluczać go z udziału we wszystkich aktywności, z których mógłby korzystać będąc poza murami więzienia. Dostęp do tych aktywności przeciwdziała w przyszłości wykluczeniu społecznemu, a także daje skazanemu, chociaż chwilową, możliwość zapomnienia o fakcie pobytu w zakładzie karnym lub areszcie śledczym.

Grupę aktywności stanowiących środki oddziaływania penitencjarnego tworzą zajęcia kulturalno-oświatowe i sportowe. Odbywają się one zarówno wewnątrz, jak i na zewnątrz budynków jednostki penitencjarnej. Zgodnie ze standardami wskazanymi w raportach $\mathrm{CPT}^{34}$, więzień musi mieć zapewniony co najmniej godzinny dostęp do zajęć na świeżym powietrzu, a także 8 godzin dziennie spędzać poza celą mieszkalną świadcząc pracę, ucząc się lub korzystając z zajęć kulturalno-oświatowych ${ }^{35}$.

\footnotetext{
${ }^{34}$ DAwidZIUK, Traktowanie osób pozbawionych wolności, s. 143.

${ }^{35}$ Raport CPT z wizyty w Polsce w 2103 r., CPT/Inf (2014)21, par. 43, [w:] http://www.isp. policja.pl/download/12/3549/raport-cpt.pdf [dostęp: 01.10.2019].
} 
Artykuł $112 \S 1$ k.k.w. gwarantuje osadzonemu prawo do godzinnego spaceru, wskazując nieliczne wyjątki, w których brak będzie możliwości realizacji tego prawa (art. $112 \S 3$ k.k.w.). Niestety w rzeczywistości penitencjarnej pola spacerowe najczęściej nie oferują nic ponad wybetonowaną przestrzeń do chodzenia dookoła i ewentualnego fragmentu trawiastego. Mało atrakcyjnie wygląda także zapewnienie osadzonym różnorakich zajęć w porze dziennej. Skazani mogą korzystać z zakładowej biblioteki oraz świetlicy, która niestety nie jest wyposażona w liczne i atrakcyjne sprzęty. W konsekwencji skazańcy spędzają większość czasu w celach mieszkalnych, gdzie niejednokrotnie wzajemnie się demoralizują ${ }^{36}$. Wskazuje na to KMPT w rocznym raporcie, podkreślając konieczność powiększenia oferty zajęć przeznaczonych dla osadzonych. Komitet odnotował także pozytywne zmiany, określając je mianem dobrych praktyk, a mianowicie: adaptacja pomieszczeń gospodarczych na bogato wyposażoną salę do specjalistycznych zajęć sportowych dla osadzonych - crossfit, joga itp. (Zakład Karny nr we Wrocławiu), modernizacja hali sportowej, gdzie osadzeni mogą grać w sporty zespołowe m.in. koszykówkę czy siatkówkę (Zakład Karny we Wronkach) ${ }^{37}$.

W zakresie sądownictwa międzynarodowego należy zauważyć, że skargi ${ }^{38}$ składane do Europejskiego Trybunału Praw Człowieka [dalej cyt.: ETPCz] w zakresie naruszenia prawa do uczestniczenia w zajęciach kulturalno-oświatowych i sportowych nie stanowią samoistnych zarzutów, ale zasadniczo łączone są z zarzutami dotyczącymi naruszenia minimalnej normy mieszkaniowej. Wyroki zapadające w wyniku tych postępowań wskazują, że połączenie zjawiska przeludnienia z brakiem lub ponadwymiarowym ograniczaniem aktywności kulturalno-oświatowych i sportowych stanowi naruszenie norm dotyczących traktowania więźniów w czasie pozbawienia ich wolności ${ }^{39}$.

W zakładach karnych typu półotwartego oraz otwartego, w przeciwieństwie do zakładu karnego typu zamkniętego, ustawodawca przewidział możliwość udziału skazanych w, organizowanych przez administrację jednostki penitencjarnej poza terenem zakładu karnego, grupowych zajęciach kulturalno-oświatowych lub sportowych (art. 91 pkt 4 i art. 92 pkt 4 k.k.w.). W celu uczestnictwa w tego typu wydarzeniach wymagane jest wydanie zezwolenia. Poniższa tabela przedstawia skale udzielonych zgód oraz ich wykorzystanie w latach 2005, 2012 i 2018.

\footnotetext{
${ }^{36}$ PawlowsKa, Prawo podmiotowe więźniów, s. 84.

${ }^{37}$ Raport Rzecznika Praw Obywatelskich z działalności w Polsce Krajowego Mechanizmu Prewencji Tortur w roku 2018, [w:] https://www.rpo.gov.pl/sites/default/files/KMPT\%20-\%20raport\%20za\%20rok \%202018.pdf [dostęp: 17.06.2019], s. 132.

${ }^{38}$ B. Stańdo-Kawecka, Prawa osób pozbawionych wolności w świetle orzeczeń Europejskiej Konwencji Praw Człowieka, Warszawa: Program Unii Europejskiej Phare/Tacis Demokracja 1998, s. 24

${ }^{39}$ Wyrok Valasinas v. Litwa z dnia 24 lipca 2001 r., skarga nr 44558/98, § 103.
} 
Tabela nr 4. Skala zezwoleń na uczestniczenie w zajęciach kulturalno-oświatowych i sportowych poza zakładem karnym w latach 2005, 2012 i $2018^{40}$.

\begin{tabular}{|c|c|c|c|c|c|}
\hline \multicolumn{3}{|c|}{ Wyszczególnienie } & 2005 & 2012 & 2018 \\
\hline \multirow{6}{*}{$\begin{array}{c}\text { Zezwolenia na } \\
\text { zajęcia kulturalno- } \\
\text { oświatowe. }\end{array}$} & \multirow{2}{*}{$\begin{array}{c}\text { W trybie art. } 91 \text { pkt. } \\
4 \text { k.k.w. }\end{array}$} & Liczba korzystających & 5000 & 14083 & 12844 \\
\hline & & Liczba zezwoleń & 7917 & 37840 & 33746 \\
\hline & \multirow{2}{*}{$\begin{array}{c}\text { W trybie art. } 92 \text { pkt. } \\
4 \text { k.k.w. }\end{array}$} & Liczba korzystających & 812 & 2248 & 1308 \\
\hline & & Liczba zezwoleń & 1627 & 5610 & 2451 \\
\hline & \multirow{2}{*}{$\begin{array}{l}\text { W trybie art. } 92 \text { pkt. } \\
5 \text { k.k.w. }\end{array}$} & Liczba korzystających & 896 & 1193 & 834 \\
\hline & & Liczba zezwoleń & 3517 & 5555 & 2464 \\
\hline \multirow{6}{*}{$\begin{array}{c}\text { Zezwolenia na } \\
\text { zajęcia sportowe }\end{array}$} & \multirow{2}{*}{$\begin{array}{c}\text { W trybie art. } 91 \text { pkt. } \\
4 \text { k.k.w. }\end{array}$} & Liczba korzystających & 3107 & 6278 & 4587 \\
\hline & & Liczba zezwoleń & 6844 & 19988 & 13379 \\
\hline & \multirow{2}{*}{$\begin{array}{c}\text { W trybie art. } 92 \text { pkt. } \\
4 \text { k.k.w. }\end{array}$} & Liczba korzystających & 717 & 917 & 402 \\
\hline & & Liczba zezwoleń & 1816 & 2098 & 766 \\
\hline & \multirow{2}{*}{$\begin{array}{l}\text { W trybie art. } 92 \text { pkt. } \\
5 \text { k.k.w. }\end{array}$} & Liczba korzystających & 313 & 258 & 437 \\
\hline & & Liczba zezwoleń & 1021 & 658 & 2422 \\
\hline \multirow{2}{*}{\multicolumn{2}{|c|}{ Ogółem }} & Liczba korzystających & 10845 & 24977 & 20412 \\
\hline & & Liczba zezwoleń & 22742 & 71749 & 55228 \\
\hline & & $\begin{array}{c}\text { Procent } \\
\text { korzystających } \\
\text { do liczby zezwoleń }\end{array}$ & $47,7 \%$ & $34,8 \%$ & $36,9 \%$ \\
\hline
\end{tabular}

Analiza danych statystycznych wskazanych w poszczególnych trzech latach pokazuje występujące prawidłowości. Liczba udzielonych skazanym zgód na udział w zajęciach kulturalno-oświatowych lub sportowych poza murami jednostki penitencjarnej była co najmniej dwukrotnie wyższa niż liczba osób, które rzeczywiście skorzystały z przyznanego zezwolenia. Szczególną dysproporcję, pomiędzy liczbą zgód (71.749), a ich wykorzystaniem (24.977), widać w 2012 r. gdzie prawie tylko 1 na 3 skazanych finalnie skorzystał z uzyskanego pozwolenia. Wzrost liczby zezwoleń nie koresponduje także ze zwiększeniem się liczby osób korzystających z zezwolenia, o które się starali. Takie zachowanie osadzonych jest niezrozumiałe, gdyż inicjatywa do udziału w konkretnej aktywności musi pochodzić od samego osadzonego. Można postawić również tezę, że duża część więźniów wnioskuje o zezwolenie wyłącznie w celu weryfikacji, czy takie zostanie im udzielone.

${ }^{40}$ Opracowano na podstawie corocznych informacji statystycznych Centralnego Zarządu Służby Więziennej, www.sw.gov.pl [dostęp: 30.05.2019]. 


\section{KONTAKTY SKAZANEGO ZE ŚWIATEM ZEWNĘTRZNYM}

Izolacja więzienna, która powoduje wyrwanie człowieka z jego dotychczasowego życia, nie może jednocześnie powodować zerwania przez skazanego więzi z pozostawionym światem. Kara pozbawienia wolności, posiada swój początek i koniec ${ }^{41}$, który powinien stanowić dla byłego więźnia moment przejściowy do nowego, ,lepszego" życia.

Standard podtrzymywania kontaktów ze światem zewnętrznym, jako przejaw realizacji zasady normalizacji, podkreślają akty prawa międzynarodowego odnoszące się do traktowania więźniów podczas wykonywania kary pozbawienia wolności. Kodeks karny wykonawczy przewiduje odpowiednie narzędzia służące temu procesowi. Poczynając od kontaktów pośrednich, realizowanych w postaci rozmów telefonicznych czy wymiany korespondencji, przez widzenia bezpośrednie na terenie jednostki penitencjarnej, a kończąc na przepustkach udzielanych w trakcie odbywania kary. Dokumenty międzynarodowe rekomendują częste sięganie po różnego rodzaju formy zezwoleń na opuszczanie jednostek penitencjarnych, bowiem służy to podtrzymywaniu więzi rodzinnych i jednocześnie zmniejsza skutki demoralizacji, która występuje w zakładach karnych.

Niestety w polskich realiach penitencjarnych więźniowie nie są umieszczani w placówkach detencyjnych znajdujących się najbliżej miejsca ich zamieszkania, co niewątpliwie utrudnia podtrzymywania kontaktów pomiędzy skazańcem a jego najbliższymi. Spowodowane jest to zarówno pojemnością zakładów karnych, jak i ich rozlokowaniem na terenie kraju. Dodatkowo, niejednokrotnie zachodzi także potrzeba przetransportowania więźnia do innej placówki oddalonej od miejsca zamieszkania jego rodziny czy znajomych.

Zakwalifikowanie więźnia do określonego rodzaju zakładu karnego, a w szczególnie uzasadnionych przypadkach jeszcze jako tzw. N, czyli szczególnie niebezpiecznego, powoduje obniżenie do minimum, w polskich warunkach penitencjarnych, kontaktów ze światem zewnętrznym. Skazani, odbywający w tym rygorze karę pozbawienia wolności, zostają objęci odpowiednim do przyznanego statusu nadzorem i kontrolą. Umieszczenie w zakładzie karnym typu zamkniętego powoduje zasadniczo utrzymywanie więzi z najbliższym $\mathrm{w}$ trybie pośrednim. Zgodnie $\mathrm{z}$ art. 90 pkt 6 k.k.w. „skazani mogą korzystać z dwóch widzeń w miesiącu, a za zgodą dyrektora zakładu karnego wykorzystać je jednorazowo". Oznacza to możliwość bezpośredniej rozmowy z rodziną w wymiarze maksymalnie 120 minut w skali miesiąca. Więźniom osadzonym w zakładzie karnym typu zamkniętego, nie przysługuje, obowiązujące w zakładach typu półotwartego i otwartego (art. 91 pkt. 7

\footnotetext{
${ }^{41} \mathrm{Z}$ wyłączeniem kary dożywotniego pozbawienia wolności.
} 
i art. 92 pkt 9 k.k.w.), prawo do udzielania przepustek, dzięki którym więźniowie mają sposobność, chociaż krótkotrwałego opuszczenia murów jednostki penitencjarnej i odświeżenia więzów rodzinnych.

Poniższe zestawienie danych statystycznych w trzech analizowanych latach, pokazuje częstotliwość udzielania oraz korzystania z przyznanych przepustek i zgód na opuszczanie murów jednostek penitencjarnych.

Tabela nr 5. Udzielone przepustki i zezwolenia na czasowe opuszczenie jednostki penitencjarnej w latach: 2005, 2012 i $2018^{42}$.

\begin{tabular}{|c|c|c|c|c|}
\hline \multicolumn{2}{|c|}{ Wyszczególnienie } & 2005 & 2012 & 2018 \\
\hline \multirow{2}{*}{$\begin{array}{l}\text { art. } 91 \text { pkt. } 7 \text { k.k.w. } \\
\text { przepustka do } 14 \text { dni }\end{array}$} & $\begin{array}{l}\text { Liczba osób } \\
\text { korzystających }\end{array}$ & 2440 & 3583 & 2973 \\
\hline & Liczba zezwoleń & 2662 & 3855 & 3265 \\
\hline \multirow{2}{*}{$\begin{array}{l}\text { art. } 92 \text { pkt. } 9 \text { k.k.w. } \\
\text { przepustka do } 28 \text { dni }\end{array}$} & $\begin{array}{c}\text { Liczba osób } \\
\text { korzystających }\end{array}$ & 3799 & 3642 & 2536 \\
\hline & Liczba zezwoleń & 5844 & 5883 & 4043 \\
\hline \multirow{2}{*}{$\begin{array}{l}\text { art. } 138 \S 1 \text { pkt. } 7 \text { k.k.w. } \\
\text { widzenie do } 30 \text { h. }\end{array}$} & $\begin{array}{l}\text { Liczba osób } \\
\text { korzystających }\end{array}$ & 17493 & 16467 & 13450 \\
\hline & Liczba zezwoleń & 46714 & 44853 & 33914 \\
\hline \multirow{2}{*}{$\begin{array}{c}\text { art. } 138 \S 1 \text { pkt. } 8 \text { k.k.w. } \\
\text { jednorazowe opuszczenie } \\
\text { do } 14 \text { dni }\end{array}$} & $\begin{array}{l}\text { Liczba osób } \\
\text { korzystających }\end{array}$ & 14438 & 12380 & 10219 \\
\hline & Liczba zezwoleń & 24128 & 22275 & 18582 \\
\hline \multirow{2}{*}{$\begin{array}{l}\text { art. } 165 \S 2 \text { k.k.w. } \\
\text { poszukiwanie pracy }\end{array}$} & $\begin{array}{l}\text { Liczba osób } \\
\text { korzystających }\end{array}$ & 622 & 476 & 211 \\
\hline & Liczba zezwoleń & 825 & 867 & 323 \\
\hline art. 141a k.k.w. & $\begin{array}{l}\text { Ogólna liczba zezwoleń } \\
\text { (z asystą i bez asysty) }\end{array}$ & 7747 & 6392 & 4106 \\
\hline \multirow{3}{*}{ Ogólem } & Liczba korzystających & 38792 & 36548 & 29389 \\
\hline & Liczba zezwoleń & 80173 & 77733 & 60127 \\
\hline & $\begin{array}{l}\text { Procent korzystających } \\
\text { do liczby zezwoleń }\end{array}$ & $48,38 \%$ & $47,01 \%$ & $48,87 \%$ \\
\hline
\end{tabular}

Analogicznie jak w przypadku zezwoleń na korzystanie z zajęć kulturalno-oświatowych i sportowych poza terenem zakładu karnego, tak i w odniesieniu

${ }^{42}$ Opracowane na podstawie corocznych informacji statystycznych Centralnego Zarządu Służby Więziennej, www.sw.gov.pl [dostęp: 30.05.2019]. 
do przepustek na opuszczenie miejsca detencji, liczba wydanych zezwoleń jest zdecydowanie większa niż liczba osób z nich korzystających.

We wszystkich wytypowanych latach najczęściej stosowanym środkiem bezpośredniego podtrzymywania kontaktów ze światem zewnętrznym były nagrody w postaci zezwolenia na widzenie, poza obrębem jednostki penitencjarnej, z osobą najbliższą lub osobą godną zaufania, na okres nieprzekraczający jednorazowo 30 godzin. Negatywnie należy ocenić widoczny trend spadkowy zarówno w samej liczbie przyznanych nagród, jak i osób z nich korzystających. Jednak w zestawieniu procentowym w 2018 r. zaobserwować należy niewielki, bo 2\%, wzrost liczby więźniów korzystających z widzenia względem wszystkich przyznanych nagród.

Drugim w kolejności mechanizmem służącym realizacji zasady normalizacji jest nagroda $\mathrm{z}$ art. $138 \S 1$ pkt 8 k.k.w. Podobnie jak w przypadku poprzedniej nagrody, również i w tym, widoczna jest tendencja spadkowa zarówno w zakresie liczby wydanych zezwoleń, jak i osób korzystających. Zaobserwowane spadki odpowiadają generalnej tendencji wskazującej na zmniejszającą się liczbę więźniów. Niepokojącą tendencję wykazuje także zmniejszające się korzystanie z zezwoleń wydawanych dla więźniów, którym kończy się odbywanie kary pozbawienia wolności. Ta grupa osób powinna być objęta szczególnym wsparciem, gdyż to oni wrócą do społeczeństwa i rozpocznie się ich nowe życie.

Podsumowując powyższe dane statystyczne niepokojące jest utrzymujące się zjawisko ponad dwukrotnie niższego zainteresowania wykorzystaniem przyznanego prawa do opuszczenia miejsca detencji. Tak duża dysproporcja uwydatnia problem w realnym podtrzymywaniu kontaktów skazanych ze światem zewnętrznym. Zgoda na wyjazd do osoby najbliższej stanowi najgłębszy wyłom w szczelnym systemie więziennym i powinna być wykorzystywana w maksymalnej częstotliwości. Praktyka pokazuje niestety, że tak nie jest.

\section{ZAKOŃCZENIE}

Środki oddziaływania penitencjarnego mają w swoim założeniu wspierać proces reintegracji skazanego w trakcie wykonywania kary pozbawienia wolności. Potrzebę ich stosowania dostrzega zarówno społeczność międzynarodowa, jak i rodzime ustawodawstwo. Różnorodność narzędzi służących temu zadaniu jest szeroka, jednak zarówno częstotliwość ich stosowania, jak i wykorzystywania, co wynika z danych statystycznych, nie znajduje się na zadawalającym poziomie.

Szczególnie niesatysfakcjonujący trend widoczny jest w odniesieniu do uczestniczenia skazanych w edukacji, zajęciach kulturalno-oświatowych i sportowych oraz kontaktach skazanych z najbliższymi. W konsekwencji, większość środków 
penitencjarnych przewidzianych przez przepisy Kodeksu, nie jest wykorzystywana z pożądanym zakresem. Na przestrzeni ostatnich lat, pozytywnie należy ocenić ciągłe zwiększanie liczby skazanych, którzy zostają zatrudnieni zarówno odpłatnie, jak i nieodpłatnie. W corocznych raportach KMPT, również podkreśla wyraźną poprawę w tym przedmiocie.

Podsumowując analizę danych poczynioną w niniejszym tekście należy stwierdzić, że pomimo licznych środków oddziaływania penitencjarnego, nie pełnią one zakładanej roli i co najbardziej negatywne, upływ czasu niestety zasadniczo nie zmienia panującego obrazu.

\section{BIBLIOGRAFIA}

\section{ŹRÓDEA PRAWA MIĘDZYNARODOWEGo}

Konwencja o Ochronie Praw Człowieka i Podstawowych Wolności sporządzona w Rzymie dnia 4 listopada 1950 r., zmieniona następnie Protokołami nr 3, 5 i 8 oraz uzupełniona Protokołem nr 2, Dz. U. z 1993 r. Nr 61, poz. 284.

Wzorcowe reguły minimalne postępowania z więźniami, przyjęte w Genewie w 1955 r. przez Pierwszy Kongres Narodów Zjednoczonych w Sprawie Zapobiegania Przestępczości i Postępowania ze Sprawcami Przestępstw i zaaprobowane przez Radę Gospodarczą i Społeczną w rezolucji 663C (XXIV) z dnia 31 lipca 1957 r. oraz rezolucji 2076 (LXII) z dnia 13 maja 1977 r., [w:] Standardy Organizacji Narodów Zjednoczonych w dziedzinie wymiaru sprawiedliwości w sprawach karnych, Warszawa: Ministerstwo Sprawiedliwości, Departament Współpracy Międzynarodowej i Prawa Europejskiego 2003.

Wzorcowe reguły minimalne Organizacji Narodów Zjednoczonych dotyczące postępowania z więźniami (Reguły Mandeli), [w:] https://www.rpo.gov.pl/sites/default/files/Reguly_Mandeli.pdf [dostęp: 21.10.2019].

Zalecenie Komitetu Ministrów Rady Europy dla państw członkowskich Rec (2006) 2 z dnia 11 stycznia 2006 r. w sprawie Europejskich reguł więziennych (przyjęte na 952 posiedzeniu wiceministrów), Przegląd Więziennictwa Polskiego 72-73 (2011).

\section{ŹRÓDŁA PRAWA KRAJOWEGO}

Ustawa z dnia 6 czerwca 1997 r. Kodeks karny, Dz. U. z 2019 r., poz. 1950.

Ustawa z dnia 6 czerwca 1997 r. Kodeks karny wykonawczy, Dz. U. z 2019 r., poz. 676.

Rozporządzenie Ministra Sprawiedliwości z dnia 12 grudnia 2016 r. w sprawie sposobu i trybu prowadzenia nauczania w zakładach karnych i aresztach śledczych, Dz. U. poz. 2004 z późn. zm.

\section{ORZECZNICTWO}

Wyrok Trybunału Konstytucyjnego z dnia 23 lutego 2010 r., sygn. akt P 20/09. Wyrok Valasinas v. Litwa z dnia 24 lipca 2001 r., skarga nr 44558/98, § 103. 


\section{LITERATURA}

DAwiDZIuk Ewa: Traktowanie osób pozbawionych wolności we współczesnej Polsce na tle standardów międzynarodowych, Warszawa: Wolters Kluwer 2013.

Kuć Małgorzata: Indywidualizacja wykonywania kary pozbawienia wolności, Lublin: Towarzystwo Naukowe KUL 2007.

Migdal Jerzy, Sкrobotowicz Grzegorz: Możliwość realizacji Europejskich Reguł Więziennych z 2006 r. w zakresie reintegracyjnego modelu wykonywania kary pozbawienia wolności a przeludnienie polskich jednostek penitencjarnych, Rocznik Nauk Prawnych 24 (2014), nr 1, s. 109-120.

Nowicki Marek A.: Wokół Konwencji Europejskiej. Komentarz do Europejskiej Konwencji Praw Człowieka, Warszawa: Wolters Kluwer 2013.

Pawıowska Natalia: Prawo podmiotowe więźniów do powierzchni mieszkalnej, Państwo i Prawo 6 (2007), s. 76-89.

Postępowanie z wybranymi grupami skazanych w polskim systemie penitencjarnym. Aspekty prawne, red. A. Kwieciński, Warszawa: Wolters Kluwer Polska 2013.

STAŃDO-KawECKa Barbara: Prawa osób pozbawionych wolności w świetle orzeczeń Europejskiej Konwencji Praw Człowieka, Warszawa: Program Unii Europejskiej Phare/Tacis Demokracja 1998.

\section{ZESTAWIENIE TABEL}

Tabela nr 1. Zestawienie danych statystycznych przedstawiających skazanych i ukaranych według grup i systemu wykonywania kary pozbawienia wolności w latach (stan na dzień 31 grudnia): 2005, 2012, 2018

Tabela nr 2. Skala zatrudnienia i płacy skazanych w latach 2005, 2012 i 2018.

Tabela nr 3. Osadzeni objęci nauczaniem w szkołach przywięziennych i pozawięziennych w latach szkolnych 2004/2005, 2011/2012 oraz 2017/2018.

\section{ZESTAWIENIE WYKRESÓW}

Wykres $\mathrm{nr}$ 1. Zestawienie danych statystycznych przedstawiających skazanych i ukaranych według grup i systemu wykonywania kary pozbawienia wolności w latach 2005-2018 (ogółem).

Wykres $\mathrm{nr} 2$. Zestawienie liczby skazanych w poszczególnych rodzajach zakładów karnych w latach 2005-2018.

Wykres nr 3. Zestawienie liczby skazanych odbywających karę pozbawiania wolności w poszczególnych systemach w latach 2005-2018.

Wykres $\mathrm{nr}$ 4. Zestawienie procentowe zatrudnienia skazanych w latach 2005-2018.

Wykres nr 5. Zestawienie liczby skazanych uczących się w różnych placówkach oświatowych w latach 2005-2018.

\section{WYKONYWANIE ŚRODKÓW ODDZIAŁYWANIA PENITENCJARNEGO NA PRZESTRZENI LAT}

\section{Streszczenie}

Izolacja penitencjarna jest niewątpliwie anormalną sytuacją życiową dla osób jej doświadczających, powodując szereg doświadczeń traumatycznych i depresyjnych. Jej skutki są odczuwalne nie tylko dla samego skazanego, ale także dla jego rodziny i osób w najbliższym otoczeniu. Potrzeba 
porzucenia obecnego stylu życia ze wszystkimi tego konsekwencjami, a także separacja od bliskich, powoduje, że przetrzymywanie w warunkach jednostek penitencjarnych staje się szczególnie bolesną dolegliwością dla skazanych.

Celem opracowania jest przedstawienie zakresu stosowania środków oddziaływania penitencjarnego na skazanych na przestrzeni ostatnich czternastu lat (2005-2018) w zestawieniu z ogólną liczbą skazanych i ukaranych. Na łamach kolejnych stron tekstu zostaną omówione poszczególne dane statystyczne publikowane w ramach corocznych raportów Służby Więziennej, co pozwoli na wskazanie zarówno działających, jak i niedziałających mechanizmów odpowiedzialnych za oddziaływanie na skazanych.

Słowa kluczowe: zakład karny; więzienie; więzień; reintegracja; resocjalizacja; kara pozbawienia wolności; środki oddziaływania penitencjarnego

\section{EXECUTION OF PENITENTIARY MEASURES OVER THE YEARS}

\section{Sum mary}

Penitentiary isolation is undoubtedly an abnormal life situation for people experiencing it and causes a number of traumatizing and depressing factors. Its effects are felt not only for the convict himself, but also for his family and people in the immediate environment. The need to abandon the current lifestyle with all its consequences, as well as separation from loved ones, all of them cause that detention in the conditions of penitentiary units becomes a particularly painful ailment for convicts.

The purpose of the article is to present the scope of penitentiary measures on convicts in the last fourteen years (2005-2018) in comparison with the total number of convicts. On the following pages of the text I will discuss the individual statistical data published as a part of the annual reports of the Prison Service, which will allow for indicating both working and non-working mechanisms responsible for the reintegration of the prisoners.

Key words: prison; jail; prisoner; reintegration; resocialization; imprisonment; penitentiary measures 